\title{
THE INSANITY DEFENSE: THE NEED FOR ARTICULATE GOALS AT THE ACQUITTAL, COMMITMENT, AND RELEASE STAGES
}

A society devising a rational legal system posits goals and then seeks the best method of attaining them; to evaluate such a system it is appropriate to isolate the society's goals and to analyze the procedures chosen for their implementation. This Note will examine rationales for permitting an insanity defense and indicate weaknesses in procedures currently employed for post-trial disposition of persons raising the defense.

\section{Justifications for and Implications of the Insanity Defense}

\section{A. Rationales}

Although rationales can be separated-for analytical purposes, the separation is artificial. Different rationales may exert an influence at the same time, and procedures to implement each may result in conflicts which negate whatever social benefits might ensue if a choice were made in favor of one rationale.

\section{The Legalistic Rationale}

A crime ordinarily consists of two elements: ${ }^{1}$ an objective act and a subjective state of mind, the mens rea, ${ }^{2}$ which may or may not require specific intent. Since the state bears the burden of proving all elements of a criminal offense, the accused's mental state is relevant even when he does not formally interpose insanity as a defense. ${ }^{3}$ Although some defend-

1 See Hall, General Principles of Criminal Law 70-104 (2d ed. 1960); Willuams, Criminal Law-The General Part 22-27 (2d ed. 1961).

2 See Dession, Criminal Law, Administration and Public Order 55-56 (1948); Keeton \& Lioyd, The United Kingdom: The Development of Its Laws and Constirumions 105 (1955); Paulsen \& Kadish, Criminal Law and Its PROCESSES 229-70 (1962).

3 The Model Penal Code expressly permits evidence "that the defendant suffered from a mental disease or defect" to come in at trial "whenever it is relevant to prove that the defendant did or did not have a state of mind which is an element of the offense." MODEL PENAL Code \$4.02(1) (Proposed Official Draft 1962). The bill currently before the Senate which alters District of Columbia procedure adopts the Code rule verbatim. H.R. 7525, 88th Cong., 1st Sess. $\$ 201$ (1963).

At times, however, states have sought to exclude evidence bearing on the accused's mental condition at trial either because they reject the defense of partial responsibility, see note 8 infra, or because of specialized procedural provisions as in California, for example, which employ the bifurcated trial procedure whenever the insanity defense is raised. Because of this procedural arrangement the courts sought, for a time, to exclude all psychiatric evidence from the first trial, in which the issue of guilt was determined. See, e.g., People v. Leong Fook, 206 Cal. 64, 273 Pac. 779 (1928). The California courts ultimately abandoned this position and now hold that to refuse to admit evidence bearing on the accused's mental ability in the first trial would be a denial of due process when such evidence has bearing on whether the accused could have the requisite mens rea. See, e.g., People v. Wells, 33 Cal. 2d 330, 202 P.2d 53, cert. denied, 338 U.S. 836 (1949); People v. Webb, 143 Cal. App. 2d 402, 300 P.2d 130 (Dist. Ct. App. 1956); Donneliy, Goldstern \& Schwartz, 
ants who plead insanity could simply contend that they lacked the requisite mens rea, ${ }^{4}$ the insanity defense is broader than the mens rea concept. For example, substitution of a mens rea inquiry for the insanity defense would not result in exoneration for a defendant charged with crimes requiring no specific mental element. ${ }^{5}$ Moreover, if insanity is a defense primarily because it negates mens rea, it seems that mental weaknesses short of insanity might be used for the same purpose. In Fisher $v$. United States, ${ }^{6}$ in which the accused was convicted of first-degree murder, the Supreme Court held that the District of Columbia district court had not erred when it gave the jury a M'Naghten instruction but refused to charge that the evidence of defendant's limited mental ability could also be considered in connection with the mens rea requirements of premeditation and deliberation. ${ }^{7}$ According to the court, such a charge would

CrIminal LAw 688-90 (1962); Louisell \& Hazard, Insanity as a Defense: The Bifurcated Trial, 49 Calif. L. Rev. 805 (1961) ; cf. Stewart v. United States, 214 F.2d 879 (D.C. Cir. 1954); Fisher v. United States, 149 F.2d 28 (D.C. Cir. 1945), aff'd, 328 U.S. 463 (1946) (evidence of borderline mentality admissible in murder prosecution, but refusal to charge on partial responsibility held no error); Goldstein \& Katz, Abolish the "Insanity Defense"-Why Not?, 72 Y ALE L.J. 853, 865 n.40 (1963).

${ }^{4}$ See Fox, Physical Disorder, Conscionsness, and Criminal Liability, 63 Corusr. L. REv. 645, 655 (1963). See generally Goldstein \& Katz, supra note 3.

5 In some situations lack of mens rea functions as the sole exculpatory device. For example, an autonomic act is not punishable. See Fain v. Commonwealth, 78 $\mathrm{Ky} .183$ (1879) (court's rejection of evidence on defendant's somnambulistic tendencies held error) ; Morris, Sommambulistic Homicide: Ghosts, Spiders, and North Koreans, 5 Res Judicatae 29 (1951) (report on King v. Cogdon, Supreme Court of Victoria, 1950). Such an act is "automatic and apparently undirected symbolic behavior which is not consciously controlled." AMIERICAN Psychiatric Ass'N, A Psychiatric GlosSARY 4-5 (1957). Somnambulism is "a general automatism occurring in the course of, and interrupting normal sleep." HeNDERSON \& GILLESPIE, A TEXTBOOK OF PSYCHIATRY 125 (7th ed. 1950); cf. People v. Hardy, 33 Cal. 2d 52, 198 P.2d 865 (1948).

Similarly, intoxication is generally held to negate specific intent. Thus, although a defendant's intoxication will not completely exonerate him, it may reduce the degree of the offense. See, e.g., People v. Baker, 42 Cal. 2d 550, 268 P.2d 705 (1954) (decision based on provision of California Penal Code); People v. Koerber, 244 N.Y. 147, 155 N.E. 79 (1926). In Proctor v. United States, 177 F.2d 656 (D.C. Cir. 1949) (per curiam), evidence of the defendant's intoxication was held immaterial since the crime-using an automobile without the owner's consent-did not require a specific intent. See also Paulsen \& Kadish, op. cit. supra note 2, at 356-59.

6149 F.2d 28 (D.C. Cir. 1945), aff'd, 328 U.S. 463 (1946).

7 The instruction requested by the defense attorney was the following:

[Y] et if the jury find from the evidence that there was such a degree of mental unsoundness existing at the time of the homicide as to render the defendant incapable of premeditation and of forming such an intent as the jury believe the circumstances of this case would reasonably impute to a man of sound mind, they may consider such degree of mental unsoundness in determining the question whether the act was murder or manslaughter.

Fisher v. United States, 328 U.S. 463, 471 n.9 (1946); cf. LINDMraN \& McINTYRE, The Mentally Disabled and tHe Law 255-57 (1961). Compare Fisher v. United States, supra, with Washington v. State, 165 Neb. 275, 85 N.W.2d 509 (1957) (error to instruct jury to consider the defendant's level of intelligence solely in connection with penalty).

The traditional M'Naghten instruction is the following:

[T] he jurors ought to be told in all cases that every man is presumed to be sane, and to possess a sufficient degree of reason to be responsible for his crimes, until the contrary be proved to their satisfaction; and that to establish a defense on the ground of insanity, it must be clearly proved that, at the 
amount to a recognition of the defense of partial responsibility ${ }^{8}$ without legislative approval. ${ }^{\ominus}$

Taken to its logical conclusion, the legalistic rationale that insanity is a defense because it negates mens rea would require complete discharge from criminal custody of an accused acquitted by reason of insanity since the state has, by hypothesis, failed to prove one of the elements of the offense. $^{10}$ However, other considerations often dictate that the acquitted defendant be committed to a mental institution. ${ }^{11}$

\section{The Community Sentiment Rationale}

The community's basic notions of fairness influence the jury to resist inflicting punishment on an "insane" defendant even though he has engaged in proscribed conduct. ${ }^{12}$ Notions of fairness may also be responsible for

time of the committing of the act, the party accused was labouring under such a defect of reason, from disease of the mind, as not to know the nature and quality of the act he was doing; or, if he did know it, that he did not know he was doing what was wrong.

M'Naghten's Case, 10 Cl. \& F. 200, 210, 8 Eng. Rep. 718, 722 (H.L. 1843).

In contrast, the charge given under the Durham rule is the following:

If you the jury believe beyond a reasonable doubt that the accused was not suffering from a diseased or defective mental condition at the time he committed the criminal act charged, you may find him guilty. If you believe he was suffering from a diseased or defective mental condition when he committed the act, but believe beyond a reasonable doubt that the act was not the product of such mental abnormality, you may find him guilty. Unless you believe beyond a reasonable doubt either that he was not suffering from a diseased or defective mental condition, or that the act was not the product of such abnormality, you must find the accused not guilty by reason of insanity.

Durham v. United States, 214 F.2d 862, 875 (D.C. Cir. 1954).

8 Partial responsibility "rests on the proposition that a defendant should not be held responsible for a degree of crime requiring as one of its elements a mental state that he was incapable of achieving." LINDMAAN \& McINTYRe, op. cit. supra note 7, at 355. See, e.g., State v. Bunk, 4 iN.J. 461, 73 A.2d 249 (1950) ; WeIHofEN, MENTAL Disorder as a CRTMInal Defense 189 (1954). Diminished responsibility, on the other hand, is an English doctrine imported from Scottish practice which permits the reduction of a murder charge to manslaughter when the defendant suffered from an "abnormality of mind .. [which] substantially impaired his mental responsibility for his acts . . ." Homicide Act, 1957, 5 \& 6 Eliz. 2, c. 11, \$2(1).

8 Fisher v. United States, 328 U.S. 463,476 (1946).

10 The jury would, of course, have the option in a murder case of convicting the accused of a lesser offense, e.g., second degree murder or manslaughter. What is contemplated here is the defendant's release when the jury returns an acquittal verdict.

11 Twelve states and the District of Columbia provide for automatic mandatory commitment, see note 46 infra, of the acquitted defendants: Colo. REv. STAT. ANN. \$39-8-4 (Supp. 1960); D.C. Code ANN. \$24-301 (d) (1961); GA. CoDE ANN. \$27-1503 (1953) ; Kan. Gen. Stat. ANN. \$ 62-1532 (1949); Me. Laws 1963, c. 311, \$17-C; MAss. Laws ANN. ch. 123, $\$ 101$ (1957) (in cases of murder and manslaughter only); MICH. CoMrp. LAws $\$ 766.15 \mathrm{c}$ (1948) (in cases of murder only); MINN. Stat. ANN. \$631.19 (Supp. 1962); NeB. Rev. Stat. \$29-2203 (1956); Nev. REv. Stat. \$ 175.445 (1961); N.Y. Code CrIM. Proc. \$ 454; OHIo Rev. Code ANN. \$2945.39 (Page 1953); WIS. STAT. \$957.11(3) (1961). For an articulation of some of the factors which may compel a legislature to enact a mandatory commitment law see S. Rep. No. 1170, 84th Cong., 1st Sess. (1955).

12 See Holloway v. United States, 148 F.2d 665, 666-67 (D.C. Cir. 1945) ("Our coilective conscience does not allow punishment where it cannot impose blame."). In an analogous area, English juries often understated the amount of money taken in a theft case to avoid imposition of the capital. penalty. See 1 RadzINowICz, A History of Englise CrIMINal LAW 94-97 (1948). 
legislative judgments establishing the insanity defense. In one of the early drafts of the Model Penal Code, the American Law Institute attempted to codify community sentiments into an insanity rule. The proposal would have permitted the jurry to determine whether or not the capacity of an accused "either to appreciate the criminality of his conduct or to conform his conduct to the requirements of law" was so substantially impaired that he could not "justly be held responsible." 13 This formulation was ultimately rejected, presumably because of its imprecision 14unguided juries in different sections of the community have varying standards of justice. ${ }^{15}$ Although it is quite clear that different juries may have different ideas of what constitutes, for example, insanity or reasonableness, these concepts have a legal flavor and the jury will presumably be made aware of the fact that it is applying legal criteria and not merely common sense. Furthermore, it is possible for the judge to limit the range within which the jury may act arbitrarily. No such limitation is possible when the jury is instructed to determine what the community's basic notions of fairness are. Adoption of an exculpatory standard which gives the jury definite directions is preferable since it provides some uniformity at least on a formal level. ${ }^{16}$ 1955)

13 Model Penal Code $\$ 4.01$ (1), alternative formulation (a) (Tent. Draft No. 4,

14 See Model Penal Code $\$ 4.01$ (1), comment (Tent. Draft No. 4, 1955):

Alternative (a) proposes to submit the issue squarely to the jury's sense of justice... Some members of the Council deemed it unwise to present questions of justice to the jury, preferring a submission that in form, at least, confines the inquiry to fact. The proponents of the alternative contend that since the jury normally will feel that it is only just to exculpate if the disorder was extreme, that otherwise conviction is demanded, it is safer to invoke the jury's sense of justice than to rest entirely on the single word "substantial," imputing no specific measure of degree.

15 Community sentiment may of course be different in various geographic areas. In addition, the jury may not be fairly representative of the community. See Broeder, The Functions of the Jury: Facts or Fictions?, 21 U. CHI. L. Rev. 386 (1954). "In addition to being an inconsistent law-dispenser, the jury is in many respects a highly unrepresentative one. If the jury is designed to function as a minor legislature it should represent a total cross-section of the community." Id. at 412-13; cf. DoNNELLY, GOLDSTEIN \& SCHWARTz, op. cit. supra note 3 , at 126-31.

16 Despite widespread criticism of the jury system as irrational, see, e.g., Frank, Courts on TRIAL 109-25 (1950), results of the University of Chicago Law School's Jury Project indicate that jurors take the performance of their function more seriously than had previously been assumed. GREgory \& Kalven, CaSES and Materials oN TORTS 128 (1959); James, Jurors' Assessment of Criminal Responsibility, 7 SocIAL Problems 58, 68 (1959). Thus, some control over the scope of the deliberations appears to be possible through the instructions given by the trial judge.

The jury acts as a safety valve; it is a "built-in check on the rigour and inflexibility of the law." The Humanist Frane 337 (Huxley ed. 1961). To some extent it is desirable that the jury temper the law with its concept of community standards of justice. However, the jury's discretion to disregard the law to achieve a more just result is limited by the legal system itself. Thus, it may be proper to charge the jury on the offense for which the accused is being tried and all the lesser included offenses only if there is evidence on all elements of a lesser included offense. See People v. Stevens, 272 N.Y. 373, 6 N.E.2d 60 (1936). This procedure may result in the entry of a compromise verdict which is permitted within limits, as long as there is evidence to sustain the compromise verdict. See Dunn v. United States, 284 U.S. 390 (1932) (inconsistent jury verdicts upheld). However, a jury determination of whether the defendant could "justly be held accountable" contains no such limits. 
Commitment to a mental institution after acquittal is less objectionable under a fairness rationale than under a legalistic one, since confinement in a mental institution need not be equated with punishment by the community. Moreover, additional pressures favoring the protection of the community may justify some type of commitment for defendants acquitted by reason of insanity. ${ }^{17}$

\section{The Pragmatic Rationale}

The insanity defense may be viewed as practically serving one or more of the desirable goals of criminal law-individual ${ }^{18}$ and general ${ }^{19}$ deterrence, incapacitation, and reformation. This is not to suggest that any of these goals should be viewed in isolation. If, for example, general deterrence were the only consideration, an acquitted offender might be released completely following the jury verdict; however, the adoption of such a procedure might disserve the reformative goal. ${ }^{20}$ On the other hand, mandatory commitment following an acquittal by reason of insanity may serve several goals simultaneously. ${ }^{21}$ Institutionalization of an acquitted defendant has clear penal overtones, but mandatory commitment statutes have survived constitutional attack. ${ }^{22}$ Under such statutes acquittal by reason of insanity is different from an ordinary acquittal. Although the conventional acquittal formula of "not guilty" is employed, the conse-

17 See, e.g., Guttmacher, Principal Difficulties With the Present Criteria of Responsibility and Possible Alternatives, in MODEL PENAL CODE $\$ 4.01$, app. B (Tent. Draft No. 4, 1955) ("It seems to me prtadent to recommend such procedure [mandatory commitment], since the community needs the assurance that actual recovery has occurred and that there is no likelihood of imminent recurrence.") ; S. REP. No. 1170, 84th Cong., 1st Sess. 13 (1955) ("The Committee believes that a mandatory commitment statute would add much to the public's peace of mind, and to the public safety, without impairing the rights of the accused.").

18 In theory the criminal law is supposed to operate as a deterrent. When, however, an individual is so mentally deranged as not to know the difference between right and wrong he is incapable of rationally directing his conduct and he will not be deterred by the threat of punishment. Cf. Alexander \& Staub, The Crnminal, THE JUDGE AND THE PUBLIC 78-79 (1956).

19 However, the community's sense of justice may be disturbed by the sight of an insane man being executed, for example. A widespread sense of injustice may lead to disrespect for, rather than obedience to, the law. See Arens \& Lasswert, IN Defense of Public ORder 24 (1961); Silving, Mental Incapacity in Criminal Law, 2 Current Law \& Social Problems 1, 7 (1961).

20 See, e.g., Mr. Justice Bok of the Pennsylvania Supreme Court dissenting in Commonwealth v. Woodhouse, $401 \mathrm{~Pa}$. 242, 265-66, 164 A.2d 98, 110 (1960):

I favor combatting crime by keeping a felon in prison, regardless of his offense, until he has been shown to be criminally harmless and no longer a menace to society. . . . The Rule [M'Naghten] is a ready method of qualifying defendants for conviction and imprisonment, but also for their release without regard for their criminal tendencies. To free dangerous people when they should remain locked up is stupid and has the opposite effect of protecting society. The Rule does this and hence is the keystone of a vengeful rather than a curative system.

21 See pages $743-47$ infra.

22 See, e.g., Ex parte Slayback, 209 Cal. 480, 288 Pac. 769 (1930); People v. Dubina, 304 Mich. 363,8 N.W.2d 99, cert. denied, 319 U.S. 766 (1943); cf. Orencia v. Overholser, 163 F.2d 763 (D.C. Cir. 1947). But see Lynch v. Overholser, 369 U..S. 705 (1962). 
quences which follow indicate that a more proper verdict might be "guilty but insane." 23

There are compelling reasons why an exponent of the pragmatic approach might support post-acquittal commitment for insane defendants. The desirability of incapacitating an individual who has perpetrated an unlawful act will weigh in favor of post-acquittal commitment. Blanket release for acquitted defendants may diminish the law's deterrent effect on noninsane members of the community. In addition, many individuals may feel a sense of injustice when an offender is set free without punishment. $^{24}$ Even though a psychiatrist might categorize such reactions as pathological, ${ }^{25}$ their influence will undoubtedly be reflected in the legal system. $^{26}$ Similarly, if one of the purposes of the legal system is to maximize the sense of security in the society, this goal will not be served if members of the community believe the legal system operates to permit dangerous individuals to go free. ${ }^{27}$

Immediate release following an insanity acquittal may encourage offenders to feign insanity to avoid punishment. ${ }^{28}$ Even if there were absolute certainty that those feigning insanity would be detected by psychiatrists, ${ }^{29}$

23 The Royal Commission objected to the use of such a verdict since it resulted in the branding of insane individuals as criminal. See Commission on Capital Punishment, Report, CMD. No. 8932, at 156-57 (1953). The suggestion here is not that such a procedure should be adopted, but that such a verdict form would more accurately reflect the disposition to be made of criminal defendants acquitted by reason of insanity. See Goldstein, Police Discretion Not To Invoke the Criminal Process: Low-Visibility Decisions in the Administration of Justice, 69 YALE L.J. 543, 544 n.4 (1960).

24 See Letter From the Late Judge Learned Hand to the University of Chicago Law Reviez, reprinted in 22 U. CrI. L. REv. 319 (1955):

[M]ost people have a feeling that "justice" requires a law breaker to suffer, just as they think that sin should entail suffering in the sinner. Personally I do not share that feeling, which is a vestige, I believe, of very ancient primitive and irrational beliefs and emotions. However, it would be unwise, and incidentally impracticable to disregard it as a constituent element; it is extremely strong in most people.

25 See Alexander \& StaUb, op. cit. stipra note 18, at 213-17; Fluger, MaN, Morals AND SOCIETY 168-70 (1945); Hill, The Psychological Realism of Thurman Arnold, 22 U. Chr. L. Rev. 377, 388-89 (1955).

26 See cases cited note 31 infra; cf. ARENS \& LASSwEL, op. cit. supra note 19, at 24; Holmes, The Common Law 41 (1881): "The first requirement of a sound body of law is, that it should correspond with the actual feelings and demands of the community, whether right or wrong." Mr. Justice Holmes' idea is not without its limitations. See Brown v. Board of Educ., 347 U.S. 483 (1954).

27 Cf. ARENS \& LASSWELL, op. cit. supra note 19, at 111-12.

28 See Lynch v. Overholser, 369 U.S. 705, 715 (1962).

29 The psychiatric profession's diagnostic and predictive abilities are somewhat inadequate at present. See 2 FreUd, Collected PAPERS 227 (Riviere transi. 1950):

Even supposing that we thoroughly know the aetiological factors that decide a given result, still we know them only qualitatively, and not in their relative strength. Some of them are so weak as to become suppressed by others, and therefore do not affect the final result. But we never know beforehand which of the determining factors will prove the weaker or the stronger. We only say at the end that those which succeeded must have been the stronger. Hence it is always possible by analysis to recognize the causation with certainty, whereas a prediction of it by synthesis is impossible.

See generally Meenl, Clinical Versus Statistical Prediction (1954); Ash, The Reliability of Psychiatric Diagnoses, 44 J. ABNormal \& Soc. Psych. 272 (1949). 
the burden on the courts and the psychiatric profession occasioned by increased use of the insanity defense would be undesirable. ${ }^{30}$ Finally, if the jury members know that the defendant will be unconditionally released following an acquittal by reason of insanity, they may be more reluctant to acquit on this ground. ${ }^{31}$ If the jury finds such a defendant guilty, he will be sentenced to a penal institution where psychiatric treatment may be inadequate. Of course, if a convict is mentally ill, he may be transferred to a mental institution; however, when he arrives via this route rather than by civil commitment, he may be segregated from the institution's other inmates and have limited privileges because of his "prisoner" status. ${ }^{32}$ Such treatment will only emphasize the penal nature of his restraint and may make psychiatric therapy correspondingly more difficult. ${ }^{33}$

30 There would undoubtedly be an increase. "Prior to the Durham decision less than 1 percent of the criminal cases tried in the U.S. District Court for the District of Columbia resulted in verdicts of not guilty by reason of insanity. . . . [In] February of 1961 it was 25 percent." H.R. ReP. No. 563, 87th Cong., 1st Sess. 4-5 (1961).

The following statistics regarding the number of acquittals by reason of insanity tend to show either that the defense is being raised more frequently or that the Durham standard permits more acquittals than the old M'Naghten standard.

\begin{tabular}{ccc} 
Year & Defendants & Verdicts of Not Guilty \\
1957 & Tried & by Reason of Insanity \\
1958 & 473 & 7 \\
1959 & 549 & 18 \\
1960 & 490 & 33 \\
1961 & 402 & 34 \\
\hline
\end{tabular}

Appellee's Petition for Rehearing en Banc, p. 8 n.11, Campbell v. United States, 307 F.2d 597 (D.C. Cir. 1962). See generally Clayton, Six Years After Durham, 44 J. AMr. JUD. Soc'y $18(1960)$.

31 The jury's concern with the disposition of an acquitted defendant is reflected in cases where the jury returns from its deliberations to inquire whether the defendant would be set free if acquitted. In the District of Columbia Circuit it is reversible error for a judge to fail to instruct the jury, when defense counsel desires it, that an acquitted defendant is automatically committed to a mental institution. See McDonald v. United States, 312 F.2d 847 (D.C. Cir. 1962) (per curiam); Catlin v. United States, 251 F.2d 368 (D.C. Cir. 1957) (per curiam) (defense counsel should not have informed jury of consequences of acquittal by reason of insanity since it was judge's duty); Taylor v. United States, 222 F.2d 398 (D.C. Cir. 1955) ; Lyles v. United States, 254 F.2d 725, 728 (D.C. Cir. 1957) (separate opinion of Prettyman \& Burger, JJ.), cert. denied, 356 U.S. 961 (1958). The argument against such instructions is, of course, that punishment is not a proper consideration for the jury which is only a trier of facts, and that informing the jury of the penalties may lead to a compromise verdict. See Pope v. United States, 298 F.2d 507 (5th Cir. 1962); Lovely v. United States, 169 F.2d 386 (4th Cir. 1948), cert. denied, 338 U.S. 834 (1949) ; cf. Dusky v. United States, 271 F.2d 385, 400-01 (8th Cir. 1959), rev'd per curian, 362 U.S. 402 (1960); Dicks v. United States, 253 F.2d 713 (5th Cir. 1958). Proposed amendments to the D.C. Code prohibit telling the jury of the consequences of the acquittal by reason of insanity. See H.R. 7525, 88th Cong., 1st Sess. $\$ 201$ (1963). However, in Lyles, supra, the court states that since the jury knows the consequences of the other two verdicts it "has a right to know the meaning of this possible verdict [acquittal by reason of insanity] as accurately as it knows by common knowledge the meaning of the other two possible verdicts." 254 F.2d at 728 .

32 Prisoners transferred to a mental institution from a penitentiary may be placed in a closed ward both to protect other patients and to prevent their escape. See generally Greenblatr, YoRk \& Brown, MENTaL Hospitals (1955).

33 See Abramamsen, Who ARe tHe Guirty? 232 (1952); Arens \& Lasswetr, op. cit. supra note 19, at 106-07; Johnston, Sources of Distortion and Deception in Prison Interviezving, 20 Fed. Prob., March 1956, p. 43; Sorensen, Interviezeing Prison Inmates, 41 J. CRIM. L., C. \& P.S. 180 (1950). 


\section{B. The Meaning of Acquittal: Significance of the Burden of Proof}

\section{When the Prosecution Bears the Burden}

In a criminal prosecution, the accused is presumed sane ${ }^{34}$ when sanity is not in issue, the prosecution need not prove it. ${ }^{35}$ Once the issue has been raised by the defendant's offering some evidence, however, proof of the defendant's sanity becomes part of the prosecution's case in most jurisdictions either beyond a reasonable doubt ${ }^{36}$ or, as has been suggested, by a preponderance of the evidence. ${ }^{37}$ Because of the ease with which the defense can place the burden on the prosecution, there may be a great temptation for the defendant to raise the sanity issue. ${ }^{38}$ But when it is the defendant who must prove he was insane at the time of the offense he may hesitate to raise the defense unless he has good reason to believe he will succeed.

In a jurisdiction in which the prosecution bears the burden of proving the defendant's sanity beyond a reasonable doubt, a verdict of acquittal "by reason of insanity" need not indicate an affirmative finding that the defendant was insane at the time of the crime, but only that the prosecution failed to convince the trier of fact that the accused was sane at that time. ${ }^{39}$ From a psychiatric point of view, mandatory commitment solely on the basis of the jury verdict in such jurisdictions is undesirable since there has been no specific finding that the defendant was insane..$^{40}$

34 Werhofen, Mental Disorder as a Criminal Defense 214 (1954) : "Sanity being the normal condition of the human mind, the prosecution may proceed, in the first instance, upon the presumption that the defendant was sane and responsible when the act was committed. To this rule all courts agree."

35 To require the Government to prove defendant's sanity in every case "would seriously delay and embarass the enforcement of the laws against crime, and in most cases be unnecessary." Davis v. United States, 160 U.S. 469, 486 (1895) (dictum).

${ }^{36}$ In twenty-four states and the District of Columbia, the prosecution bears the burden of proving sanity beyond a reasonable doubt. See WeInoFEN, op. cit. supra note 34, at 241-72; Territory v. Adiarte, 37 Hawaii 463, 469 (1947); State v. Violett, 111 N.W.2d 598, 607 (S.D. 1961) (dictum); State v. Esser, 16 Wis. 2d 567, 588, 115 N.W.2d 505, 516 (1962).

37 At present there are apparently no jurisdictions in which the state has the burden of proving the defendant's sanity by a preponderance of the evidence. See WeIHOFEN, op. cit. supra note 34, at 241-72. But see Comment, Professor George H. Dession's Final Draft of the Code of Correction for Puerto Rico, 71 Y YLE I.J. 1050, 1095 (1962):

Since the proper disposition of an offender is as much a concern of the state as of the offender, the code provides that it shall be the duty of the prosecutor or court as well as the attorney for the offender to raise the issue of responsibility. . . . It is not, however, clear why such finding . . . must be proven beyond a reasonable doubt . ... since the issue does not go to the participation of the defendant in a situation, upon which invocation of the code is predicated, but to the disposition of the offender after such participation is established. If retribution is irrelevant to all such dispositions, arguably the question of responsibility need not require such a high quantum of proof.

38 Compare ABA Canon of Professional Ethics 5 with id. 30.

39 See Overholser v. Lynch, 288 F.2d 388, 396 (D.C. Cir. 1961) (Fahy, J., dissenting), rev'd, 369 U.S. 705 (1962).

40 Automatic mandatory commitment statutes have survived constitutional attack. See Ragsdale v. Overholser, 281 F.2d 943 (D.C. Cir. 1960). But cf. Lynch v. Overholser, 369 U.S. 705 (1962). 
Despite the fact that in a jurisdiction in which the prosecution bears the burden of proof mandatory commitment may be psychiatrically unsound, other values may influence the legislature's decision to require this result. For example, legislators may feel that the community needs optimum protection from such individuals which can only be achieved if they are institutionalized, ${ }^{41}$ or that the release of these defendants may encourage other members of the community to engage in lawless conduct. Certainly institutionalization of such defendants would prevent them from violating the law at least during the period of their restraint, and it might discourage other potential offenders from attempting to use the insanity defense to gain early release.

If the prosecutor's burden were to show sanity by a preponderance of the evidence, the psychiatric considerations opposing mandatory commitment are less weighty. Because of the ease with which the prosecution could meet a preponderance burden, a jury acquittal by reason of insanity would be more indicative of an affirmative finding of insanity than in a beyond-a-reasonable-doubt jurisdiction. ${ }^{42}$

\section{When the Defense Bears the Burden}

In a jurisdiction in which the defense bears the burden of proving insanity, acquittal by reason of insanity represents an affirmative finding that the accused was insane at the time of the offense. ${ }^{43}$

Twenty-three states ${ }^{44}$ place the burden of proving insanity on the accused. Allocating the risk of error to the defendant in this situation is not unfair since he is attempting to refute the ordinary presumption of sanity and may therefore have to establish any circumstances entitling him to

41 See, e.g., S. Rep. No. 1170, 84th Cong., 1st Sess. 13 (1955).

42 If a jurisdiction adopts the preponderance rule, the burden the prosecution would have to bear is not as stringent as in a beyond-a-reasonable-doubt jurisdiction. Considering the fact that most juries are reluctant to acquit on the ground of insanity, if the prosecution is unable to introduce sufficient evidence to sustain this burden and the jury acquits, it is highly likely that the accused was suffering from a mental disorder at the time of the crime. See Reid, Disposition of the Criminally Insane, 16 RUTGERS L. REv. 75, 112 (1961).

43 There is no constitutional prohibition preventing any state from placing the burden of proving insanity on the defendant. Leland v. Oregon, 343 U.S. 790 (1952). The defendant challenged, under the due process clause, the Oregon statute which placed the burden of proving insanity beyond a reasonable doubt on him. The Supreme Court upheld the statute. But see Frankfurter, J., dissenting:

Oregon is the only one of the Forty-eight States that has made inroads upon that principle [forcing the prosecution to prove guilt] by requiring the accused to prove beyond a reasonable doubt the absence of one of the essential elements for the commission of murder, namely culpability for his muscular contractions.

Id. at 804-05. The Oregon statute has since been amended; now the defendant bears the burden of proving his insanity by a preponderance of the evidence. ORE. REV. STAT. $\$ 136.390$ (1961).

44 WEIHOFEN, op. cit. supra note 34 , at 212 . The burden is also on defendant in Alaska. See Chase v. State, 369 P.2d 997 (Alaska 1962). It is unclear where the burden of proof lies in Arizona, Maryland, and North Dakota. 
exculpation. ${ }^{45}$ In addition, requiring the defendant to prove his insanity may decrease the number of spurious insanity defenses.

When a defendant bearing the burden of proof is acquitted by reason of insanity, the acquittal represents an affirmative finding that he was insane at the time of the offense. Here there would be more psychiatric justification for some type of post-acquittal treatment.

\section{Goal Choices and Their Implementation in the Post-Acoutttal Stage}

Once it has been determined that some type of post-acquittal disposition is in order for a defendant exculpated by reason of insanity, the problem becomes one of selecting the best procedure for implementing the goals chosen. Separation of "insane" defendants from those to be treated as ordinary offenders takes place at the trial stage; in a mandatory commitment jurisdiction, ${ }^{46}$ the only separating mechanism is the exculpatory rulewhether M'Naghten, Durham, irresistible impulse, or the Model Penal Code formulation. If the goals of mandatory commitment are therapeutic and protective, the exculpatory rule should be designed to isolate only those individuals who need treatment and from whom the society needs protection; ${ }^{47}$ otherwise psychiatric facilities will not be utilized in the most efficient manner. None of the exculpatory rules focuses on either the defendant's amenability to treatment or his danger to the community; ${ }^{48}$ thus, although they exculpate the defendant, they do not determine whether he should be set free or confined to an institution.

\section{A. Treatment as the State's Dominant Goal}

\section{When the Burden Is on the Defendant}

In this situation, an acquittal by reason of insanity represents an affirmative finding that the accused was insane at the time of the offense,

45 Lindman \& McINTYRE, op. cit. supra note 7, at 351.

$46 \mathrm{~A}$ mandatory commitment jurisdiction is one in which the judge must commit the defendant to a mental institution following his acquittal by reason of insanity. An automatic mandatory commitment jurisdiction is one in which the defendant is committed without further inquiry into his mental state. In some mandatory commitment jurisdictions there are further proceedings; the acquitted defendant must be committed only, when the proceedings reveal that he remains insane or dangerous or both. In this Note "mandatory commitment jurisdiction" will refer to a jurisdiction which requires further proceedings following defendant's acquittal; when defendant's commitment follows his acquittal without further inquiry the jurisdiction will be referred to as an "automatic mandatory commitment jurisdiction." All other jurisdictions which permit institutionalization of acquitted defendants will be referred to as "discretionary commitment jurisdictions."

47 See text accompanying notes 72-73 infra.

48 The exculpatory rule may perform a different function; it is employed at the trial stage and permits the jury to make a moral judgment phrased in terms of right and wrong. "Every criminal trial conveys a moral lesson. . . . [T] his function of the criminal trial is vital to the maintenance of a moral order . . . " RocHe, The Criminal Mind 79 (1958). 
but it does not follow that this insanity continues up to the time of the trial.49

When the jurisdiction uses the M'Naghten rule as its separatory device, the degree of mental impairment necessary before a defendant can qualify for exculpation is quite high,,$^{50}$ and a person so impaired might conceivably be commitable under a standard civil commitment statute. ${ }^{51}$ Because the M'Naghten rule is not an accurate index of either dangerousness or amenability to treatment, but merely represents a standard the community regards as minimal before penal sanctions may be imposed, many states provide for separate proceedings following an insanity acquittal in which the inquiry is whether or not the acquitted defendant is still insane or dangerous. ${ }^{52}$

\section{a. Mandatory Commitment}

Even though automatic mandatory commitment of defendants acquitted by reason of insanity may be undesirable since it can result in the crowding of institutions with untreatables, other goals may be served by such a plan. The defendant, while institutionalized, will be unable to violate the law; thus the goal of incapacitation is served. The general deterrent function is arguably strengthened since the society will not have to face the anomaly of freeing a man who has engaged in criminal conduct. The society's retributive instincts will also be gratified since some seemingly punitive action is being taken against the offender.

When the Durham rule performs the separating function, there may be even more reason for having a separate inquiry into the defendant's

49 The defendant may recover temporarily or permanently. A temporary recovery is known as a remission; at times it is difficult to determine whether a given individual has recovered or is merely in a state of remission. But see S. REp. No. 1170, 84th Cong., 1st Sess. 13 (1955): "[I] th just and reasonable . . . that the insanity, once established, should be presumed to continue and that the accused should automatically be confined for treatment until it can be shown that he has recovered." For a precise psychiatric definition of remission see note 76, infra. See Noyes \& KolB, MODERN CiInical Psychiatry 416-17 (5th ed. 1958). "In some cases the course [of schizophrenia] is continuously progressive; in others it is intermittent. More frequently it is a question of remissions and relapses which [sic] . . . there occur periods of adjustment at a lower level for a considerable period of time." Recurrences of manic depressive psychosis are "not uncommon." Id. at 369 . See also LANDIS \& Bolles, Textbook of Abnormal Psychology 128 (rev. ed. 1950).

50 "[W]e know that most inmates of institutions for the insane, if examined in regard to their knowledge of right and wrong, would pass the test perfectly." Guttmacher, The Psychiatrist as an Expert Witness, 22 U. CHI. L. REv. 325, 328 (1955); see Kuh, The Insanity Defense-An Effort To Combine Law and Reason, 110 U. PA. L. REv. 771, 776 (1962).

51 Civil commitment standards are diverse. Only five jurisdictions retain dangerousness to himself and others as the sole involuntary hospitalization criterion; other states permit involuntary hospitalization on the basis of the patient's need for care. See Lindaran \& McINTYRE, op. cit. sipra note 7, at 17. PA. Stat. Ans. tit. 50, $\$ \S 1203$ (c), 1072(11) (1954), provide for involuntary hospitalization when an individual suffers from a mental illness which "so lessens the capacity of a person to use his customary self-control, judgment and discretion in the conduct of his affairs and social relations as to make it necessary or advisable for him to be under care."

52 E.g., Ky. R. CRIM. P. 9.90(2) ; N.C. Gen. Stat. \$122-84 (Supp. 1963), in which separate proceedings are required. 
mental condition following his acquittal. As in the case of the M'Naghten rule, Durham is not an accurate index of the defendant's dangerousness or amenability to treatment; in theory at least the rule permits acquittal of defendants less seriously impaired than defendants acquitted under the $M$ 'Naghten rule. As the exculpatory requirements are more relaxed, the possibility increases that some defendants not needing confinement may be acquitted. ${ }^{53}$ Such individuals would not be amenable to treatment, and to institutionalize them, except for purposes of observation, would be a waste of institution space.

At present only twelve states and the District of Columbia provide for automatic mandatory commitment of acquitted insanity defendants; ${ }^{54}$ in seventeen states an acquitted insanity defendant will be committed only if his insanity continues, ${ }^{55}$ and in three additional states a defendant will be committed only if the civil commitment standards are met. ${ }^{56}$

Automatic mandatory commitment of acquitted defendants may deter defendants from raising the insanity defense except in the most serious offenses. ${ }^{57}$ To the extent that the insanity defense is designed to secure rehabilitative therapeutic treatment, this goal is disserved when potential patients are deterred from raising the defense. ${ }^{58}$ An additional factor which may discourage reliance on the defense is the length of time defendants have served in mental institutions following their acquittal. ${ }^{50}$ If a defendant ends up in a penal institution because he was deterred from raising the insanity defense, psychiatric treatment is rendered increasingly difficult. The penal environment is not an ideal milieu in which to attempt

53 Congress was undoubtedly cognizant of this danger; the statutory requirement that all defendants acquitted by reason of insanity be committed to a mental institution was inserted in the District of Columbia Code immediately following the celebrated Durham decision. See S. REP. No. 1170, 84th Cong., 1st Sess. 8-10 (1955).

54 See note 11 supra.

55 Ala. Code tit. 15, $\$ 429$ (1958); Cal. Pen. Code $\$ 1026$; HawaIr Rev. Ilaws \$258-38 (Supp. 1961) ; IdAHo Code ANN. \$19-2320 (1948); ILl. ANN. Stat. ch. 38, $\$ 592$ (Smith-Hurd Supp. 1962); INd. ANN. STAT. \$9-1704(a) (Supp. 1961) (or if recurrence highly probable); KY. R. CRrM. P. 9.90(2); MD. ANN. Code art. 59, $\$ 8(a)$ (Supp. 1963); Mass. Laws ANN. ch. 123, \$101 (1957) (in all cases except murder and manslaughter); MicH. CoMp. LAws \$ 767.27 (Supp. 1961) (cases other than murder); Miss. Code ANN. \$2575 (1956); Mo. ANN. Stat. \$546.510 (Supp. 1962) ; Mont. Rev. Codes Ann. \$94-7420 (1947); N.J. Stat. Ann. \& 2A:163-3 (1953); TeX. Code Crns. Proc. art. 932b, §1 (Supp. 1963); WasH. Rev. Code ANN. $\$ 10.76 .040$ (1961) (still insane or danger of recurrence); W. VA. CODE ANN. $\$ 6198$ (1961).

56 See Arrz. R. Crrm. P. 288; La. Rev. Stat. \$§ 28:53, $28: 59$ (1950); Wyo. Stat. AnN. \& 7-242 (1957).

57 See Overholser v. Lynch, 288 F.2d 388 (D.C. Cir. 1961), rev'd, 369 U.S. 705

(1962); Note, Implementation and Clarification of the Durhan Criterion of Criminal Irresponsibility, 58 CoLUM. L. REv. 1253, 1267 (1958).

58 See Schwartz, Professional Responsibility and the Administration of Criminal Justice 183 (1961).

59 See Clayton, Six Years After Durham, 44 J. Am. Jud. Soc'y 18, 21 (1960):

In all 29 cases, with the exception of the three murderers, those released as cured have spent just about about as long in the hospital as they would have spent in prison if they had been convicted and sentenced. . . . Almost anyone in his right mind would prefer a term in prison to a term in a mental hospital. 60 See note 33 supra; Sasz, LAw, Liberty aNd Psychiatry 144 (1963). 
psychiatric therapy. ${ }^{60}$ In addition, the other prisoners' attitude tends to discourage him from seeing a psychiatrist. ${ }^{61}$ If a prisoner is psychotic he may, of course, be transferred to a mental institution; ${ }^{62}$ however, only the most disturbed prisoners will usually benefit from such transfer provisions.

On the other hand, defendants may be encouraged to employ the insanity defense more frequently in jurisdictions in which there is no mandatory commitment following an acquittal. ${ }^{63}$ This possible advantage is offset by the jury's reluctance at the trial stage to acquit a defendant if they know that there is substantial chance he will be set free. Thirty-eight states do not have automatic mandatory commitment for acquitted insanity defendants; these states provide for commitment of acquitted defendants under a variety of formulae: when the defendant's insanity continues, ${ }^{64}$ when he is dangerous, ${ }^{65}$ or when a recurrence of his mental disorder is "highly probable." ${ }^{6}$ Three of the states permit commitment of acquitted defendants only if the standards for civil commitment

61 The prison society may discourage contacts with psychiatrists. See THE Sociology of PunIshment AND CoRRECTION 93-94 (Johnston, Savitz \& Wolfgang eds. 1962) ; Von Hentig, The Limits of Penal Treatment, 32 J. CRIM. L., C. \& P.S. 401, 409 (1941): "The prisoner distrusts both our healing skill and our eagerness to cure. $\mathrm{He}$ is, therefore, non-cooperative."

62 See, e.g., N.J. Stat. ANN. § 30:4-82 (Supp. 1963), which provides for transfer of insane individuals to mental institutions. It provides for transfer pursuant to a court order and for release upon recovery.

63 See note 30 supra, in which the numerical rise in insanity acquittals is reported. To some extent this increase is a direct result of the less stringent Durham standards, i.e., some of these defendants would not have been acquitted under the M'Naghten rule, but would have raised the defense anyway. However, it is clear that the Durham rule caused increased interest in mental problems; the defense might not have been raised in many of these cases prior to the Durham decision. See generally Clayton, Six Years After Durham, 44 J. Ars. Jud. Soc'y 18 (1960).

The following jurisdictions reject automatic mandatory commitment, but provide for mandatory commitment of acquitted defendants: ALASKA STAT. \$12.45.110 (1962); Conn. Gen. Stat. Rev. \$ 54-37 (Supp. 1961); Fla. Stat. \$919.11 (1961); Hawam REv. Laws \$258-38 (Supp. 1961) ; IDaHo CoDe ANN. \$19-2320 (1948); Ill. ANN. Stat. ch. 38, \& 592 (Smith-Hurd Supp. 1962); IND. ANN. STAt. \$ 9-1704a (Supp. 1963); Miss. Code AnN. \$2575 (1956); N.H. Rev. Stat. ANn. \& 607:3 (Supp. 1963); Okla. Stat. ANN. tit. 22, \$1161 (1958); UtaH Code ANN. \$77-24-15 (1953); Wyo. Stat. AnN. § 7-242 (1957).

64 Ala. Code tit. 15, 429 (1958) ; CaL. PEN. Code § 1026; HawaII Rev. Laws \$258-38 (Supp. 1961) ; IdAmo Code ANN. \$19-2320 (1948); Ir.. AnN. Star. ch. 38, $\$ 592$ (Smith-Hurd Supp. 1962); KY. R. CRIM. P. 9.90 (2) ; MD. ANN. CoDE art. 59, \$ 8(a) (Supp. 1963); Mo. AnN. Stat. \$ 546.510 (Supp. 1962); Mont. Rev. Codes ANN. \$94-7420 (1947); N.J. Stat. AnN. \$2A:163-3 (1953); Tex. Code Crim. Proc. art. 932b, \$ 1 (Supp. 1963); UTAE Code ANN. \$72-24-15 (1953); W. VA. Code ANN. $\$ 6198$ (1961). Two additional states not included in the group of thirty-eight have rejected automatic mandatory commitment for certain classes of acquitted defendants. See MASS. LAwS ANN. ch. 123, $\$ 101$ (1957) (applicable to all defendants except those charged with murder or manslaughter); MrCH. CoMr. LAws $\$ 767.27$ (1948) (applicable to defendants charged with all felonies except murder).

65 Araska Stat. \$12.45.090 (1962); Fla. Stat. \$919.11 (1961); Iowa Code ANN. \$785.18 (1950); Miss. Code ANN. \$2575 (1956); N.H. Rev. Stat. ANN. \$ 607:3 (Supp. 1963); N.C. Gen. Stat. \$ 122-84 (Supp. 1963); N.D. Cent. Code $\$ 12-05-03$ (1960); OrLa. Stat. AnN. tit. 22, \$1161 (1958); Ore. Rev. Stat. \$ 136.730 (Supp. 1961); R.I. Gen. LAws ANN. \& 26-4-7 (1956); S.D. CODE \$ 34.3672 (Supp. 1960); VT. Strat. ANN. tit. 13, \$4805 (1958); VA. CODE ANN. \$19.1-239 (1960); Wase. Rev. Code ANN. \$10.76.040 (1961).

66 INd. ANn. Stat. \$9-1704a (Supp. 1963). 
are met. ${ }^{67}$ The primary objection to such an arrangement is that it may provide insufficient protection for the society. In many situations, an insane defendant's mental illness may be in remission by the time of his trial and acquittal; this might preclude institutionalization notwithstanding the strong possibility that his illness may recur.

In Indiana, an acquitted defendant faces mandatory commitment if the judge finds "the recurrence of such an attack [of insanity] is highly probable." ${ }^{88}$ The difficulty involved in the application of this standard is ilustrated in Wyatt $v$. State. ${ }^{69}$ In that case the defendant was acquitted by reason of insanity; in the proceeding following his acquittal, three psychiatrists testified on the statistical probability of a recurrence of his illness. A fourth psychiatrist testified that he did not think defendant's illness would recur. On the basis of this evidence the trial court ordered the defendant's commitment to a mental institution. The state supreme court reversed defendant's commitment on the ground that there was "no evidence of probative value to establish a presumption . . . that this appellant, whose liberty is here at stake, would suffer a recurrence of insanity." 70 Psychiatric prediction on recurrence in a given case is fraught with difficulty ${ }^{71}$ even though an individual psychiatrist might be willing to act on the basis of his prediction, it is unwise to permit the society to commit an individual on such a basis. ${ }^{72}$

Similar problems of psychiatric prediction are encountered when mandatory commitment is automatic for acquitted defendants who are found dangerous. The meaning of "dangerous" is unclear; some argue that the dangerous standard contemplates the possibility that the defendant may commit a crime similar to the one for which he was tried. ${ }^{73}$ Other commentators argue that the standard should be limited to a prediction that the defendant is likely to engage in violent criminal activity. ${ }^{74}$

67 See note 56 supra. An additional six states fail to articulate commitment standards for acquitted insanity defendants. See statutes cited note 81 infra. Tennessee, the thirty-eighth state, has no statutory provision on this subject.

68 Ind. Ann. Stat. \$ 9-1704a (Supp. 1963).

69235 Ind. 300,133 N.E.2d 471 (1955).

70 Id. at 306, 133 N.E.2d at 475.

71 See note 29 supra.

72 See Overholser v. Lynch, 288 F.2d 388, 397 (D.C. Cir. 1961) (Fahy, J., dissenting), rev'd, 369 U.S. 705 (1962) ; Commonwealth v. Jenkins, 21 Pa. D. \& C.2d 413 (Ct. Quarter Sess. 1960) ; Goldstein \& Katz, Dangerousness and Mental Illness: Some Observations on the Decision To Release Persons Acquitted by Reason of Insanity, 70 YALE L.J. 225, 237 (1961).

73 See Overholser v. Russell, 283 F.2d 195 (D.C. Cir. 1960) ; Goldstein \& Katz, supra note 72, at 235 ; Reid, Disposition of the Criminally Insane, 16 Rutgers L. Rev. 74, 128 (1961).

74 See Overholser v. Lynch, 288 F.2d 388, 396 (D.C. Cir. 1961) (Fahy, J., dissenting), rev'd, 369 U.S. 705 (1962) ; Krash, The Durham Rule and Judicial Administration of the Insanity Defense in the District of Columbia, 70 YALE L.J. 905, 945 (1961). 
The recovery standard, i.e., an acquitted defendant will be committed unless he has recovered, is adopted by another group of states. ${ }^{75}$ It is similarly ambiguous-it is unclear whether or not an individual whose illness is in a state of remission can properly be considered recovered. ${ }^{76}$ It may be argued that mental institutions make release decisions on this basis all the time; however, there is a significant difference in the present situation. An acquitted defendant's mental illness has caused him to engage in criminal activity; the consequences of a recurrence may be a repetition of the criminal activity. If the law permitted such individuals to be set free too easily, the protective goal would be disserved.

The use of a recovery mandatory commitment standard has further implications when the problem of commitment procedures is analyzed. The applicable standard-be it recovery, dangerousness, continuing insanitymust be understandable to the individual or body which ultimately makes the commitment decision. When a standard such as recovery or continuing insanity is employed, however desirable it may be from a psychiatric point of view, it may force the decision-making individual or body to become a rubber stamp for expert testimony. ${ }^{77}$

When a jury is the body making the determination, as it is in ten states, ${ }^{78}$ this objection is more valid than in states which have the judge decide the commitment issue. The judge may be more accustomed to dealing with expert testimony since he makes commitment decisions in involuntary civil commitment proceedings. ${ }^{70}$ Thus, it may be more desirable to have a judge rather than a jury make the commitment determination for acquitted insanity defendants.

\section{b. Discretionary Conmitment}

As soon as a shift is made from mandatory to discretionary commitment procedures there may be an appreciable decrease in the general as

75 Ala. Code tit. 15, $\$ 429$ (1958); CAL. PEN. CoDE $\$ 1026$ (commitment unless defendant has fully recovered) ; HawaII REv. LAws \$ 258-38 (Supp. 1961) (defendant must show recovery); IDAFo CODE ANN. \$19-2320 (1948); ILL. ANn. STAT. ch. 38, \$ 592 (Smith-Hurd Supp. 1962); KY. R. CRIM. P. \$9.90(2); MD. ANN. CodE art. 59, \$ 8(a) (Supp. 1963) ; MICH. CoMp. LAws \$766.15c (1948) (applicable only in cases other than murder); MISs. CoDE ANN. $\$ 2575$ (1956) (jury must determine whether the accused has been restored to reason and whether he is dangerous); Mo. Ann. Stat. $\$ 546.510$ (Supp. 1962) (jury must state whether person is entirely and permanently recovered); Monr. Rev. Codes ANN. \$94-7420 (1947); N.J. STAT. ANn. \$2A:163-3 (1953); Tex. Cone CrrM. Proc. art. 932b, \$1 (Supp. 1963); UTAR CoDe ANN. \$77-24-15 (1953); W. VA. CODE ANN. \$ 6198 (1961).

76 See Hinste \& Camprele, Psychiatric Dictronary 641 (3d ed. 1960), which defines remission as an "abatement of the symptoms and signs of a disorder of disease. The abatement may be partial or complete. Physicians use the expression remission to denote amelioration, which even if complete for the time being, does not necessarily imply permanent cure; in fact, the term carries the idea that the amelioration of the symptoms is temporary."

${ }^{77}$ But see James, Jurors' Evaluation of Expert Psychiatric Testimony, 21 Oнто ST. L.J. 75 (1960). Based on the University of Chicago's Jury Project findings, the author discovered that $71 \%$ of the juries in the study voted against expert witnesses. Id. at 95 .

78 See note 95 infra.

79 See Lindman \& Mcintyre, The Mentally Disabled and the Law 23 (1961). There are also nonjudicial involuntary commitment procedures. See $i d$. at 30 . 
well as the individual deterrent effect of the law. In a discretionary commitment jurisdiction, many of the difficulties already enumerated, e.g., jury reluctance to acquit, will be encountered with increasing frequency. From this perspective, discretionary commitment procedures may be objectionable regardless of the formula.

Some of the discretionary commitment states employ commitment formulae identical to those used by mandatory commitment states. ${ }^{80}$ However, most of the statutes which permit the judge to commit in his discretion fail to provide him with any standards. ${ }^{81}$ Such an approach to the problem can hardly lead to uniform state practice-one judge may commit insanity defendants because he feels the society needs protection, and still another because he thinks the defendants are in need of treatment. To the extent that a particular judge's reasons for commitment reflect the community's wishes there can be little objection to discretionary commitment under statutes which fail to set out standards. However, articulation of the community's long range objectives could conceivably lead to a change in short range goals. For example, although the society's retributive instincts might be satisfied if all acquitted defendants were punished rather than institutionalized, the legislature may decide that in the long run it would be better to "treat" such defendants in the hope that when they recover they will no longer engage in criminal activity. An individual judge making a commitment decision without legislative standards can at best effectuate short range goals; even if he were able to consider long range objectives before making a commitment decision, the impact of one judge's long range program would be quite limited unless he could persuade all his colleagues to adopt his approach.

\section{c. The Release Decision}

Every system, whether it adopts a mandatory or discretionary commitment approach to post-acquittal disposition of the insane defendant, has

80 N.C. GEN. STAT. §122-84 (Supp. 1963) provides that an acquitted defendant shall be committed after a hearing if the court finds him dangerous because of his mental condition and if "his confinement for care, treatment, and security demands it ...."

There is some question whether a discretionary commitment system differs in practice from a mandatory system because of the community pressure on the individual or body making the commitment decision which may force it to commit in every case.

See S. REP. No. 1170, 84th Cong., 1st Sess. 13 (1955):

No recent cases have come to the attention of this Committee where a person acquitted in the District of Columbia of a crime on the sole ground of insanity has not been committed to a mental hospital for treatment. Nevertheless, the Committee is of the opinion that the public is entitled to know that, in every case where a person has committed a crime as a result of mental disease or defect, such person shall be given a period of hospitalization and treatment to guard against imminent recurrence of some criminal act by that person.

81 ARk. Stat. ANn. \$59-242 (Supp. 1963) (commitment upon probable cause); Conn. Gen. Stat. Rev. \$ 54-37 (Supp. 1961); Del. Code Ann. tit. 11, \$4702(a) (Supp. 1962) (on motion of Attorney General) ; N.M. STAT. ANN. \$ 41-13-3 (1953); PA. Stat. AnN. tit. 19, § 1351 (1930); S.C. Code ANN. § $32-969$ (1962). 
to provide standards and procedures which can be used for the release of institutionalized persons. In the ordinary civil commitment situation, the patient is released when the personnel of the mental institution determine that he has recovered or is no longer dangerous. ${ }^{82}$ The procedures governing the release decision are largely informal and determined by the institution's needs. There will, as a rule, be no judicial intervention. Some states adopt a similar approach for defendants acquitted by reason of insanity. ${ }^{83}$ This may reflect a community judgment that the proper end of commitment is treatment when provision for such release is expressly made, or it may indicate a legislative lack of awareness of the importance of coordinating the commitment and release decisions. ${ }^{84}$ If the legislative goal was treatment of the offender, then it seems logical that he should be released when he has recovered. Clearly the institution personnel are best equipped to make this determination; so from a therapeutic point of view it would be desirable to permit psychiatrists to make the release determination. However, once the release standard is other than the patient's recovery, there are less persuasive reasons for permitting institution personnel alone to make the release decision.

Most states require judicial approval before an acquitted insanity defendant can be released; ${ }^{85}$ the statutory schemes do, however, generally permit either the institution or the patient to initiate release proceedings. To some extent, substituting the judiciary for the institution as final arbiter of whether a given defendant shall be released may represent a partial rejection of the therapeutic approach; this is particularly true when the release standard requires both that the patient have recovered and that he no longer be dangerous. Interjection of the judiciary into this area may also represent a community judgment that the release decision should be made by a politically responsible group whose concern will be for community as well as individual welfare.

States have adopted varying formulae of release standards; some provide that acquitted defendants may be released when they are "no longer insane," 86 when they are "entirely and permanently recov-

82 Cf. PA. Star. ANn. tit. 50, \$1481 (1954), a bill of rights for the mentally ill which recognizes a right in the patient "to be released as soon as he is restored to mental health and competent to manage his own affairs." This section has also been interpreted to apply to acquitted insanity defendants in institutions. See Commonwealth v. Jenkins, 21 Pa. D. \& C.2d 413 (Ct. Quarter Sess. 1960).

83 See, e.g., Kan. Gen. Stat. ANN. \$62-1532 (1949).

84 Many states make no special provision for release of defendants acquitted by reason of insanity. See collection of state statutes in LINDMAN \& McINTYRE, $o p$. cit. sispra note 79, at 373-82. (1953).

85 E.g., OHio Rev. Code ANn. §2945.39 (Page 1954) ; Utan Code Ann. § 77-24-15

86 Colo. Rev. Stat. Ann. \$ 39-8-4(3) (1953) ; Conn. Gen. Stat. Rev. § 54-38 (1958); Ilc. Ann. Stat. ch. 38, \$592 (Smith-Hurd Supp. 1962); Ind. Ann. Stat. \$ 9-1705 (1956); Mp. ANN. CoDE art. 59, \$8 (Supp. 1963); Mich. Conr. LAwS \$767.27 (Supp. 1961); Minn. Stat. \$631.19 (1957); N.J. Stat. Ann. \$2A:163-2 (1953) ; N.C. GeN. Stat. \$122-84, -86 (Supp. 1963) (general assembly assent for 
ered," 87 or if they "will not in the reasonable future be dangerous to [themselves] or others." 88 The "no longer insane" and "entirely and permanently recovered" standards appear to disregard the possibility that some individuals may be sane but dangerous. The difficulty with the "danger in the foreseeable future" criterion is that psychiatrists are forced to make predictions that are beyond their competence. In addition, application of this standard could conceivably result in life-time institutionalization for some individuals. ${ }^{89}$ The Model Penal Code adopts what may be the best approach to the problem of release standards. It permits release of institutionalized defendants when the court finds "that the person committed . . . may be discharged or released on condition without danger to himself or others." 80 This standard takes into account the necessity of focusing on the individual's dangerousness but does not require psychiatric prediction to the extent that the District of Columbia standard does.

The Code contemplates that the major release initiative will come from the state officials in charge of institutions, but to prevent official lethargy and to circumvent possible constitutional difficulties, the patient is permitted to file release petitions at six-month intervals. ${ }^{91}$ Official filing of petitions is not limited, but in the ordinary situation it is clear that the institution will be forced to reevaluate the patient's condition at least every six months since it knows the patient will file a request for release. Placing this burden on the institution to reexamine all institutionalized insanity defendants is desirable since it avoids the possibility of protracted confinement due to institutional indifference. The Code wisely limits the number of release petitions a patient may file, it is better to permit a full judicial review of the facts every six months than to require $a d$ hoc screening by the court of release petitions every few weeks.

acquitted murderers; governor's order for other criminals); OHIo Rev. CoDE ANN. $\$ 2945.39$ (Page 1958); Tex. Code CrIm. Proc. art. 932b, \$6 (Supp. 1963); UTAH Code AnN. \$ 77-24-15 (1953); VA. Code ANN. \$ 37-93 (1953); Wrs. Stat. § 957.11(4) (1961).

Other states permit release if it is not incompatible with public welfare. DEL. Code AnN. tit. 11, \$4702(c) (Supp. 1962); ME. Rev. Stat. AnN. ch. 27, \&120 (1954); N.H. REv. STAT. ANN. \$607:4 (1955) (discharge by governor and council); Pa. Stat. Ann. tit. 50, \$1304(a) (1954).

87 Ixt. Ann. Stat. ch. 38, §592 (Smith-Hurd Supp. 1962).

88 D.C. Code ANn. $\$ 24-301$ (e) (2) (1961). The District of Columbia also requires that the patient be recovered. The proposed bill permits release of acquitted defendants when the court is satisfied "that the committed person may be discharged or released on probation without danger to himself or others . . ." H.R. 7525, 88th Cong., 1st Sess. \& $201(\mathrm{~h})(3)$ (1963).

89 See Arens \& Lasswell, In Defense of Public Order 46 (1961); de Grazia, The Distinction of Being Mad, 22 U. CHI. L. REv. 339 (1955); Goldstein \& Katz, Dangeronsmess and Mental Illness: Some Observations on the Decision To Release Persons Acquitted by Reason of Insanity, 70 Y ALE L.J. 225, 237 (1961) ; cf. Commonwealth v. Jenkins, 21 Pa. D. \& C.2d 413 (Ct. Quarter Sess. 1960).

90 Model Penal Code $\$ 4.08(2)$ (Proposed Official Draft 1962).

91 Four states limit the number of release petitions which a confined individual may file. See Cal. Pen. Code \$ 1026a; INd. ANN. Stat. \$ 9-1705 (1956); UTAH Code ANN. §77-24-16 (1953); WIS. StaT. \$51.11(8) (1961). 


\section{When the Burden Is on the Prosecution}

When the prosecution bears the burden of proving defendant's sanity, mandatory commitment of such defendants is not justified from a psychiatric point of view since there is no indication, at least by the verdict, that they are or have ever been in need of medical treatment. Nevertheless, many states provide for mandatory commitment when the burden of proof is on the prosecution. ${ }^{92}$ These states may have determined, in light of the difficulty of proving the defendant's sanity beyond a reasonable doubt, ${ }^{93}$ that society must be given the maximum protection. This protection could only be provided when individuals successfully involing the defense are institutionalized. If automatic mandatory commitment is used, the burden of proof of sanity should be placed on the defendant at trial so that a definite judgment is made about his sanity before he is routed to a mental institution.

\section{B. When the State's Dominant Goal Is Protection}

When the state's dominant goal is protection, it is immaterial for analytical purposes which party bears the burden of proof. The only concerns are whether or not the defendant engaged in the criminal activity and, if he did, whether he is likely to repeat this conduct.

Taking into account the unreliability of psychiatric prediction, in a state with a protective philosophy there would be a greater tendency to provide for automatic mandatory commitment than in a state with a therapeutic orientation. On the other hand, some protectionists may feel that their goal can be achieved more satisfactorily if acquitted defendants were treated rather than merely incapacitated; in this respect the protective and therapeutic goals overlap. Automatic mandatory commitment may neutralize the jury's antidefense bias although it may result in the crowding of institutions with untreatables.94 For this reason, even a protectionist may reject automatic mandatory commitment in favor of mandatory commitment for dangerous defendants.

92 All the jurisdictions listed in note 63 supra, except Alaska, place the burden of proving insanity on the prosecution. See WEIHOFEN, op. cit. silpra note 34 , at 241-72; Territory v. Adiarte, 37 Hawaii 463, 469 (1947). But see Chase v. State, 369 P.2d 997 (Alaska 1962). Seven of the thirteen jurisdictions having automatic mandatory commitment place the burden on the prosecution beyond a reasonable doubt: Colorado, District of Columbia, Kansas, Massachusetts, Michigan, Nebraska, and New York.

${ }^{93}$ See Kuh, The Insanity Defense-An Effort To Combine Law and Reason, 110 U. PA. L. Rev. 771, 776 (1962): "If the prosecution must prove that disease was absent or that the crime did not result from it, and must do so by proof beyond a reasonable doubt, then-assuming that juries are able to and do follow instructions -the prosecution can seldom be successful."

94 A combination of the Durham rule and automatic mandatory commitment does not appear to have resulted in institutionalization of improper subjects according to the psychiatric staff at St. Elizabeth's. See Washington Post, Aug. 9, 1959, p. E1, col. 1, reprinted in Donneliy, Goldstein \& Schwartz, Criminal LaW 809 (1962). Only five of the ninety defendants did not deserve acquittal by reason of insanity. Four of these individuals were released in less than three months; the other spent six months in St. Elizabeth's. Id. at 810. 
In a predominantly protective-oriented state, there would probably be a tendency to place the responsibility for making the release decision in the hands of a judge and perhaps even a jury. ${ }^{95}$ The standards by which an individual defendant's readiness for release are measured would undoubtedly be the danger he presents to the community.

\section{A Suggested Approach}

Statutory arrangements for insane defendants should balance both treatment and protective goals. Disregarding the problem of the best exculpatory rule, the best post-acquittal system seems to be mandatory commitment under, perhaps, a "dangerous to himself or others" standard.96 An acquitted defendant might be committed immediately following his trial to an institution for a sixty- or ninety-day period to permit a thorough study to be made of his personality. ${ }^{97}$ At the conclusion of the period, there would be a judicial inquiry. ${ }^{98}$ The judge should have several alternative methods of disposing of the case: if he finds the acquitted defendant "dangerous to himself or others," the judge could commit the defendant to a mental institution; if he believes there is a possibility that the defendant's illness might recur, the judge could, nevertheless, release him on probation; ${ }^{99}$ or if the judge is convinced that the defendant is not presently dangerous and there is little possibility that he will become so in the future, he could release the defendant unconditionally. Release of defendants committed to mental institutions under the first alternative would be adequately handled under the Model Penal Code provisions governing release. ${ }^{100}$

95 Most states permit the trial judge to make the decision whether or not to release; however, ten states permit a jury to make the determination. The trial jury makes the determination in Illinois, Maryland, Mississippi, Missouri, New Jersey, Oklahoma, Texas, and Washington. The judge is permitted, in his discretion, to call a second jury in Idaho and Montana.

86 This is the standard generally employed in involuntary commitment proceedings; thus it is one the judge will be accustomed to applying. See note 79 sipra and accompanying text. It would also assure the institution of receiving defendants who were in need of treatment. See Guttmacher, The Psychiatrist as an Expert Witness, 22 U. CHr. L. REv. 325, 328 (1955).

97 Many state statutes provide for involuntary temporary or observational hospitalization for a sixty- or ninety-day period. See LINDMAN \& MclNTYRE, op. cit. supra note 79, at 89-91. It has been assumed that such a period is sufficient for diagnostic purposes. A similar release scheme was proposed in a Note, Procedure for the Release of the Criminally Insane-A Suggested Approach, 1962 WAsE. U. L.Q. 120 .

98 The practice in a majority of the states is that the judiciary as a politically responsible body has some role in making the commitment decision. See text accompanying note 85 supra.

99 The Model Penal Code suggests probation as an alternative to complete release. The scheme, according to the reporters, "furnishes additional protection to the public in the case of those individuals who need some supervision upon their return to the community." Moded PenAi Code $\$ 4.08(3)$, comment (Tent. Draft No. 4, 1955). Only seven states at present have such a procedure. Ibid.

100 The only real difficulty with the Model Penal Code's release proposal is that although it limits the number of release petitions a party may file it makes no attempt to do away with habeas corpus. Although there may be some constitutional objections to curtailing this important right, it virtually renders the limit on release petition filings meaningless. 
The implementation of this suggested post-acquittal system would both relieve the pressure from the exculpatory rule and render interinstitutional transfer standards less important. Formulation of an exculpatory rule to segregate the mentally ill from the "normal" offender would be less important since employment of the mandatory commitment technique after a hearing would, by removing the jury's antidefense bias, presumably result in more acquittals. The procedure is also designed to insure that only those patients in need of treatment remain institutionalized. Furthermore, under this scheme the interinstitutional transfer provisions will be used less as a device for correcting errors made by jurys' refusal to acquit and more as a method of rerouting prisoners who have become mentally ill while in jail.

Provision for probation as an alternative to commitment in the Model Penal Code represents an attempt to maintain contact with acquitted offenders for a long period of time. Mental disorders may recur beyond the period in which supervision by means of commitment to a mental institution would be justified; ${ }^{101}$ probation is a less objectional method of supervising such individuals.

Frederica B. Koller

101 Remissions may be of many years' duration. See note 49 supra; Guttmacher, The Psychiatrist as an Expert Witness, 22 U. CHr. L. REv. 325, 329 (1955). 